\title{
Submandibular Gland Squamous Cell
} Carcinoma

National Cancer Institute

\section{Source}

National Cancer Institute. Submandibular Gland Squamous Cell Carcinoma. NCI

Thesaurus. Code C5943.

An invasive squamous cell carcinoma that arises from the submandibular gland. It usually affects elderly patients and presents as a rapidly enlarging tumor mass, often associated with pain. 